\title{
Self-Cleaning Coatings and Surfaces of Modern Building Materials for the Removal of Some Air Pollutants
}

\author{
Anna Rabajczyk*(D), Maria Zielecka (D), Wojciech Klapsa (D) and Anna Dziechciarz (D) \\ Scientific and Research Centre for Fire Protection-National Research Institute, Aleja Nadwiślańska 213, \\ 05-420 Józefów, Poland; mzielecka@cnbop.pl (M.Z.); wklapsa@cnbop.pl (W.K.); adziechciarz@cnbop.pl (A.D.) \\ * Correspondence: arabajczyk@cnbop.pl; Tel.: +48-22-769-32-69; Fax: +48-22-769-33-73
}

check for updates

Citation: Rabajczyk, A.; Zielecka, M.; Klapsa, W.; Dziechciarz, A. Self-Cleaning Coatings and Surfaces of Modern Building Materials for the Removal of Some Air Pollutants. Materials 2021, 14, 2161. https:// doi.org/10.3390/ma14092161

Academic Editor: Neven Ukrainczyk

Received: 12 March 2021

Accepted: 21 April 2021

Published: 23 April 2021

Publisher's Note: MDPI stays neutral with regard to jurisdictional claims in published maps and institutional affiliations.

Copyright: (c) 2021 by the authors. Licensee MDPI, Basel, Switzerland. This article is an open access article distributed under the terms and conditions of the Creative Commons Attribution (CC BY) license (https:/ / creativecommons.org/licenses/by/ $4.0 /)$.

\begin{abstract}
Air quality is one of the most important problems of the modern world, as it determines human health and changes occurring in other elements of nature, including climate change. For this reason, actions are taken to reduce the amount of harmful substances in the air. One such action is the use of building materials with special properties achieved by the application of self-cleaning coatings and photocatalytic additives. This article presents achievements in the field of additives and modifiers for building materials, whose task is to improve air quality. Concrete, cement, paints, and facade coatings modified based on the achievements of nanotechnology have been analyzed in terms of new properties and the possibility of their application in the area of modern environmental requirements. Both positive aspects and doubts were described in the scope of the effective reduction of the amount of gases such as $\mathrm{VOC}, \mathrm{NO}_{\mathrm{x}}$, dust and microorganisms.
\end{abstract}

Keywords: modified building materials; air pollution; self-cleaning; photocatalysis; antibacterial properties

\section{Introduction}

Air pollution is increasing year by year. This is mainly the case in urban areas and industrial areas. Air quality is determined by the presence and concentration/amount of various gaseous substances, dusts and aerosols. Among air pollutants, the most important are $\mathrm{CO}_{2}$, nitrogen oxides $\left(\mathrm{NO}_{\mathrm{x}}\right)$, polycyclic aromatic hydrocarbons (PAHs) and volatile organic compounds (VOCs), heavy metals (including $\mathrm{Pb}, \mathrm{Cd}, \mathrm{Cu}, \mathrm{Cr}, \mathrm{Ni}, \mathrm{Se}, \mathrm{Zn}$ ) and dust $\left(\mathrm{PM}_{2.5}-\mathrm{PM}_{10}\right)$. It should be noted, however, that not only the presence of these compounds is important, but also the reactions in the atmosphere with the participation of these compounds. Organic compounds in reaction with nitrogen oxides determine ozone formation in the lower atmosphere, which is particularly important in regions with very high summer temperatures. Pollutants present in the air undergo further chemical and physical changes, creating other dangerous substances and causing deposits and patina on architectural objects, which contributes to the degradation of building materials.

One of the intensively developed ways of removing some pollutants from the air is the use of self-cleaning building materials [1]. Architectural objects made of such materials can have a significant impact not only on improving air quality but also on increasing aesthetics in urban or industrial zones.

Based on the literature data, the following types of self-cleaning building materials surfaces can be distinguished:

- Oleophobic/superhydrophobic with a contact angle $>150^{\circ}$ and reducing the amount of adsorbed soil [2-4];

- Hydrophilic/super hydrophilic having a contact angle $<10^{\circ}$ and facilitating the removal of water pollution, e.g., during rainfall [5];

- Oleophobic-hydrophilic with a contact angle $<10^{\circ}$ for water and an angle $>150^{\circ}$ for non-polar substances, which reduces the amount of adsorbed dirt and facilitates the removal of impurities [6-8]; 
- Photocatalytic containing additives decomposing impurities.

Obtaining such surface properties of building materials generally requires the application of appropriate coating materials or the introduction of additives that modify the composition and structure of the building material.

The purpose of this paper is to systematize information on recently developed building materials with self-cleaning surfaces, in particular biomimetic superhydrophobic or superhydrophilic surfaces as well as photocatalytic ones decomposing pollutants. A literature review was made using the following databases: Web of Knowledge, Scopus, and Google Scholar. The research also covered Espacenet, Patentscope, and Google Patents, which resulted in the presentation of selected patents relevant to the subject.

\section{Surface Wettability}

As is known, the self-cleaning properties of the surface are primarily related to the contact angle formed by the drop of liquid placed on the substrate after reaching equilibrium, which is described by the Young-Dupré equation [9]. The surface of the coating material is perfectly wetted when $\theta=0$, while it is hydrophobic when $\theta \geq 90^{\circ}$. Generally, during measurements the contact angle hysteresis is determined by the difference of increasing and decreasing contact angle. The ideal state could only occur if the solid surface was completely smooth, chemically homogeneous, and the measurement was carried out slowly enough so that the state of all surfaces was as close to equilibrium as possible. In fact, roughness has a significant effect on surface wettability, as described by Wenzel and Cassie [10]. The Wenzel theory describes a rough surface completely wetted by a liquid that penetrates all substrate structures, whereas the Cassie model applies to a rough surface with a very regular structure forming the so-called composite surface in which the air is occluded in unevenness. This reduces the wettability and creates a superhydrophobic surface with a contact angle above $150^{\circ}$ [10].

In recent years, both basic research and application works in the field of coating materials with superhydrophobic and superhydrophilic properties obtained thanks to the designed regular structure and surface chemical structure have been intensively developed $[11,12]$. Based on the processes and systems naturally present in the environment (e.g., lotus leaf, rice leaf, butterfly wings), a wide range of materials with designed surface properties have been designed and are still being designed. For their production, polymers, ceramics, metals or hybrid composite systems are used. An overview of such self-cleaning surfaces is presented in Table 1. 
Table 1. An overview of such self-cleaning surfaces.

\begin{tabular}{|c|c|c|c|}
\hline $\begin{array}{l}\text { Artificial Bioinspired } \\
\text { Surface Architecture }\end{array}$ & Surface Properties & Surface Texture and Chemistry & Ref \\
\hline Lotus leaf & Superhydrophobic, low adhesion & $\begin{array}{l}\text { Hydrophobic epicuticular wax and papillae giving dual (micro/nano) scale roughness } \\
\text { responsible for superhydrophobic self-cleaning effect. PDMS used for fabrication of lotus } \\
\text { leaf replica. WCA } 160^{\circ} \text { while WCA of flat PDMS surface } \sim 110^{\circ} \text {. }\end{array}$ & [13] \\
\hline Gecko feet & Superhydrophobic, high adhesion & $\begin{array}{l}\text { Nanopillar array with nanoscale ends (spatula) creating high adhesive forces due to van der } \\
\text { Waals interactions. PDMS on nanopillar arrays fabricated by using electron-beam } \\
\text { lithography covered with poly(dopamine methacrylamide-co-methoxyethyl acrylate). }\end{array}$ & [14] \\
\hline Rose petals & Superhydrophobic, high adhesion & $\begin{array}{l}\text { Hierarchical micro papillae and nanofolds giving sufficient surface roughness for } \\
\text { superhydrophobic properties and high adhesive forces due to Cassie impregnating wetting } \\
\text { state. Poly vinyl alcohol for fabrication of rose petals template. WCA 154.6 }\end{array}$ & [15] \\
\hline Fish scale & Superoleophilic in air, superoleophobic in water & $\begin{array}{l}\text { The scales have oriented pappilae, } 100-300 \mu \mathrm{m} \text { long and } 30-40 \mu \mathrm{m} \text { in diameter, arranged in a } \\
\text { radial direction, which provide excellent self-cleaning properties. Polyacrylamide for } \\
\text { replication of the fish scale structrure. WCA } 160^{\circ} \text { OCA }<5^{\circ} \text { in air and }>\sim 160^{\circ} \text { in water. }\end{array}$ & [16] \\
\hline Shark skin & Hydrophilic, oleophilic & $\begin{array}{l}\text { Small tooth-like scales. Replica of the surface by using polyvinylsiloxane } \mathrm{WCA} 0^{\circ} \text { in air and } \\
\qquad 109^{\circ} \text { in water. }\end{array}$ & [17] \\
\hline Rice leaf & Superhydrophobic, low adhesion, anisotropic & $\begin{array}{l}\text { Dual scale (micro\&nano) surface roughness arranged parallelly to surface giving anisotropic } \\
\text { wettability. PDMS surface chemically modified with alkanethiol to enhance hydrophobicity. } \\
\text { WCA } 136^{\circ} \text {. }\end{array}$ & [18] \\
\hline Snail shell & Hydrophobic, oleophilic & $\begin{array}{l}\text { Surface roughness of a composite of aragonite and protein. Possibility of many applications, } \\
\text { incl. ceramic tiles, sanitary fittings used in toilets and bathrooms and kitchens. WCA } 80^{\circ} \\
\text { OCA } 10^{\circ} .\end{array}$ & [19] \\
\hline Butterfly wings & Superhydrophobic, low adhesion & $\begin{array}{l}\text { Micro-nano hierarchical and periodic structure. Hydrophobic fumed silica (HDK H2000) in } \\
\text { segmented thermoplastic polydimethylsiloxane-urea copolymer. WCA 150 }\end{array}$ & {$[20]$} \\
\hline
\end{tabular}

PDMS—Polydimethylsiloxane; WCA—water contact angle; OCA—oil contact angle. 
Solutions that have been used as superhydrophobic coatings on building materials will be discussed.

Lotus effect ${ }^{\circledR}$ surface is one of the most known concepts of such a composite structure surface based on the lotus leaf self-cleaning behavior described by Barthlott [2,21]. The superhydrophobic properties of a lotus leaf are associated with the presence of wax particles on the leaf surface characterized by regular nano-scale roughness. Paints enabling the lotus leaf effect have found the widest application for the production of self-cleaning building materials. The superhydrophobic surface effect is usually obtained by using as a binder organic inorganic hybrid polymer materials often containing polysiloxanes or fluoropolymers and acrylic resins [22-24]. It is also possible to produce superhydrophobic surfaces using hydrophobic silica nanoparticles [25]. The use of rich chemistry of silicon compounds and reactive polysiloxanes allows for the use of sol-gel processes [26,27]. A superhydrophobic coating material can be fabricated by the sol-gel processing of longchain 3-methacryloxypropyltrimethoxysilane and fluorosilanization [28]. In recent years, the use of many other methods for the preparation of superhydrophobic coatings, e.g., spin-coating [29,30], dip-coating [31,32], plasma treatment [33], chemical etching [34,35], electro-spinning [36,37] and layer-by-layer (LBL) assembly [38], has been described.

Quan et al. [39] found that in the case of superhydrophobic surfaces that are arranged obliquely, the self-cleaning process can take place in two ways, i.e., collecting particles via the water-air interface and by releasing impact droplets from the surface. In addition, they found that the wettability of the particles has no effect on the self-cleaning of superhydrophobic surfaces and a higher initial kinetic energy is needed for the droplets to remove hydrophilic dust particles [39].

It should be added that surface properties are important, as they may change under the influence of interaction with water and other external parameters. The surface is exposed to degradation and/or blockage by charges and radicals present in the air. The poor mechanical stability of some superhydrophobic surfaces determines their applicability in practice. It was found, inter alia, that the thickness of the PDMS layer is important for the photocatalytic properties of $\mathrm{TiO}_{2}$. The thinner the PDMS layer, the better the photocatalysis efficiency [40]. Contrastingly, Xiong [41], in his research, showed that the optimal superhydrophobic surface formed on the cathode aluminum substrate has a maximum contact angle of $161^{\circ}$ and a maximum polarization resistance of $1591 \mathrm{k} \Omega$ $\mathrm{cm}^{2}$, indicating an excellent barrier against chemical corrosion. It was also found that the application of the electrodeposition method of thin layers of superhydrophobic cobalt stearate determines the resistance to UV radiation [41]. She et al. [42] by combining electrodeposition with chemical modification, they obtained a stable superhydrophobic surface with a cone-like structure on AZ91D magnesium alloy. The obtained surface has a very low slip angle of $1.2 \pm 0.9^{\circ}$ and is characterized by both good mechanical and chemical stability as well as good long-term durability, anti-corrosion and self-cleaning effect. The method of obtaining a superhydrophobic surface can be used on other metallic materials, including building structures [42]. Xu et al. [43] proposed another, but effective and additionally environmentally friendly method involving the use of a solution immersion method to create a superhydrophobic surface on a copper mesh. The superhydrophobic surface was obtained using the dip method. The obtained surface was characterized by a dendritic rough structure, low surface energy, while the contact angle was $155.5^{\circ}$. In addition, the tests carried out by the authors showed that the material has excellent: anti-fouling and self-cleaning properties, chemical stability in both acidic and alkaline solutions, and anti-corrosion effect (thanks to the air pockets that have formed between the superhydrophobic surface and the water that can block the corrosion process well) [43].

However, the use of developed materials and methods of their application or manufacture encounters considerable difficulties in relation to building materials. An important reason is that porous building materials possess very complicated surface characteristics. The water vapor permeability of treated and untreated building materials should be similar. In the event of non-compliance, the surface of the building material may be damaged 
and the surface layer may even delaminate. It is worth noting that in a situation where porous building materials were covered with a superhydrophobic coating, i.e., a coating with a contact angle $>150^{\circ}$, and if there was no suitable porous structure to allow water vapor diffusion, this would not be considered an appropriate solution. At the same time, most technologies for producing or applying coatings make it impossible to use them to protect building materials. Therefore, practical applications are limited and the most widely used on the market are paints giving a superhydrophobic surface with the lotus leaf effect [44,45].

Superhydrophobic surfaces play an important role in activities aimed at protecting the facades of buildings exposed to environmental pollution. Due to their hydrophobic properties, they can be used to protect against compounds such as hydrocarbons or against the unauthorized application of substances such as paints used by the authors of graffition the facades. Carrascosa et al. [46] in their work combined the features of a superhydrophilic coating with hydrophobic impregnation in order to prevent water penetration into the porous structure of the substrate. The starting solution, which consisted of $\mathrm{TiO}_{2}-\mathrm{NPs}$, silica oligomer (to ensure good adhesion to the substrate) and polydimethylsiloxane (as a hydrophobic agent), was sprayed onto concrete. In this way, the authors obtained a photo-induced superhydrophilic surface. Based on the conducted research, it was found that the obtained surfaces changed from superhydrophobic to superhydrophilic under the influence of sunlight. These surfaces showed underwater superolophobia, and the oilcontaminated dust was easy to clean without the use of detergents. In addition, they were characterized by adequate adhesion to the substrate and good resistance to precipitation and external exposure [46].

\section{Photocatalysis}

Building materials, in order to meet the performance requirements set in recent years, must, in addition to superhydrophobic properties, also have photocatalytic properties. Therefore, in recent years, research teams have focused on investigating building materials or paints containing photocatalytic additives decomposing impurities.

According to the definition of the International Union of Pure and Applied Chemistry (IUPAC), photocatalysis is a process in which, under the influence of UV, visible or infrared radiation, the reaction rate or its initiation changes. A necessary element is the presence of a photocatalyst, which absorbs light and is involved in the chemical transformation of reactants. Photocatalysis is classified as so-called groups of advanced oxidation processes. The semiconductor, built of valence, band gap and conductivity, is excited by absorbing radiation of a specific wavelength. The amount of energy supplied must be large enough for the electron from the valence band to be transported to the conductivity band. This process determines redox reactions. An excited electron in the conductivity band reacts with oxygen. As a result of the reaction, a superoxide anion radical is first formed, and as a result of further transformations hydrogen peroxide is formed. Ejection of the electron in the valence band creates the so-called holes $(\mathrm{h}+)$, which is responsible for highly hydrophilic conversion [47-49].

Photogenerated holes diffuse onto the surface and are trapped in places of oxygen in the network. Then, there is a reaction that leads to the formation of hydroxyl radicals. The resulting products, i.e., hydrogen peroxide and hydroxyl radicals, belong to strong oxidants, which in reaction with organic compounds can lead to the decomposition of these compounds into carbon dioxide and water. Among many materials or compounds such as $\mathrm{ZnO}, \mathrm{CeO}_{2}, \mathrm{SnO}_{2}, \mathrm{ZrO}_{2}, \mathrm{CdS}, \mathrm{ZnS}, \mathrm{WSe}_{2}, \alpha-\mathrm{Fe}_{2} \mathrm{O}_{3}, \mathrm{SrTiO}_{2}, \mathrm{WO}_{3}$, tested for use in photocatalysis processes, $\mathrm{TiO}_{2}$ is the best due to its high photocatalytic activity, physical and chemical stability in the dark $[47,49,50]$, no corrosion, non-toxicity and availability, and low cost. Therefore, $\mathrm{TiO}_{2}$, known as white pigment, is most often used as an additive to building materials.

There are many crystalline forms in which $\mathrm{TiO}_{2}$ is present; however, tetragonal anatase and rutile are the most common [51,52]. It should be noted that not all of these forms 
can act as a photocatalyst. Anatase and rutile have similar titanium-oxygen bond lengths; however, the angles between oxygen-titanium-oxygen bonds are more distorted in anatase. This is a consequence of differences in the arrangement of octahedrons $\left[\mathrm{TiO}_{6}\right]$ building individual polymorphic variants of $\mathrm{TiO}_{2}$. Therefore, the structure of anatase is more open than rutile, which makes the variety of anatase metastable, and has higher photocatalytic activity, while rutile is more chemically stable but less active in terms of photocatalysis. Some $\mathrm{TiO}_{2}$, being a mixture of anatase and rutile, have higher activity compared to pure anatase or pure rutile [53-55].

The applicability of $\mathrm{TiO}_{2}$ is therefore determined by the crystallographic structure as well as morphology and electronic structure. Therefore, research is being carried out involving modifications of $\mathrm{TiO}_{2}$ to obtain materials that are efficient in terms of photocatalysis, but at the same time physically and chemically stable. $\mathrm{TiO}_{2}$ is used in substances for coating photocatalytic layers of sound absorbing screens placed along traffic routes, tunnel wall surfaces and concrete road surfaces, wall surfaces in operating theatres as a disinfection element. Photocatalytic layers are obtained on ceramic materials used in construction, such as bathroom tiles that allow for odor removal [56,57]. The addition of $\mathrm{TiO}_{2}$ allows for, among others, a reduction of various organic compounds from groups such as aliphatic alcohols, halogenated compounds, alkanes and amine (Figure 1). The decomposition of organic compounds in the photodegradation process produces less toxic products, such as $\mathrm{CO}_{2}$ and water. However, the effectiveness of these processes depends on the intensity of radiation, the presence of other compounds, and the presence of competing reactions $[58,59]$.

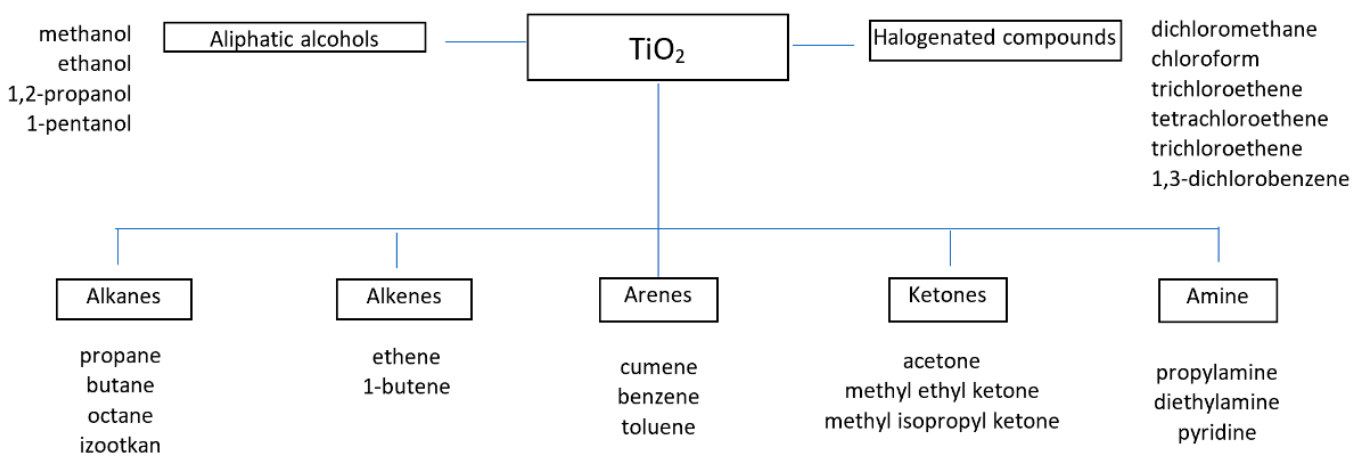

Figure 1. Organic pollutants removed from the air in the process of photocatalysis with $\mathrm{TiO}_{2}$.

The addition of $\mathrm{TiO}_{2}$ also enables the reduction of other compounds, such as $\mathrm{NO}_{\mathrm{x}}$ in the air, $\mathrm{CO}_{2}$ photoconversion, water decomposition, photooxidation of highly toxic cyanide ions, photodegradation of a group of chemical substances that are a potential threat to the environment, which are imidazolium ionic liquids.

$\mathrm{TiO}_{2}$ surface chemistry is also an important issue, which affects the angle of contact of water adhering to the surface under the influence of radiation. $\mathrm{TiO}_{2}$-coated surfaces are ultra-hydrophilic in the course of the radiation, whereas, if the radiation stops, the surface slowly regenerates and a hydrophobic surface is created. Re-irradiation restores the ultrahydrophilic properties of the coating [60]. The adsorption of organic compounds on the surface of the $\mathrm{TiO}_{2}$ film affects the transition of the structure from hydrophilicity to hydrophobicity. The effective photocatalytic decomposition of these organic contaminants would allow the surface to maintain superhydrophilicity $[49,61,62]$ and preserve the selfcleaning of the $\mathrm{TiO}_{2}$ film $[49,58]$.

Also important, the contact angle with water for several metal oxides, such as $\mathrm{WO}_{3}$ and $\mathrm{V}_{2} \mathrm{O}_{5}$, decreases in response to UV radiation. Thus, the photocatalytic decomposition of pollutants adsorbed on the surface may influence the phenomenon of surface wetting $[58,59,63]$. One hypothesis indicates that the efficiency of photoinduced superhydrophilic conversion strongly depends on the intensity and wavelength of actinic light. The initial stage of photocalytic decomposition involves photo-excitation of electrons and 
generation of charge carriers $[58,64]$. It has also been found that the hydrophilic conversion depends on the temperature and acidity of the surface. The change of surface acidity changes the trapping efficiency of charge carriers, which in turn determines the interaction between surface hydroxyl groups and outer hydroxyl layers, and thus affects the efficiency of photo-induced hydrophilic conversion $[58,59,64]$. It should be added that the electronic structure near the surface is significantly different than that in the material depth, which determines many macroscopic effects and phenomena on surfaces, including surface energy (tension), adhesion forces and specific chemical reactivity of individual surfaces. This, in turn, influences interactions with other substances and the mechanisms of these interactions [65]. The activity of the photocatalyst is determined not only by the air composition and radiation intensity [66], but also by the size of the forbidden gap, and thus the structure and size of crystallites. It was found that in the case of $\mathrm{TiO}_{2}$ made of crystal grains with a size of 1-10 nm, the forbidden gap is greater than for a single crystal. Due to the extension of the effective forbidden gap of materials made of nanoparticles, the redox potential of photo-excited electrons and holes is higher. In addition, the shorter path of migration from the inside of such a semiconductor means that the photocatalyst is characterized by a greater number of electron-hole $(\mathrm{e}-)-(\mathrm{h}+)$ pairs that are present on the surface and responsible for the efficiency of the photooxidation process. High nano- $\mathrm{TiO}_{2}$ activity in photocatalytic processes has been demonstrated, among others, in the processes of 1-butene gas phase oxidation or propyne hydrogenation, where n- $\mathrm{TiO}_{2}$ with a size of about $5 \mathrm{~nm}$ was used $[55,62,67,68]$.

It should be noted, however, that titanium dioxide absorbs only ultraviolet radiation, so the photocatalytic process can only occur when exposed to such light. Therefore, the modification is carried out in such a way as to obtain properties not only increasing its durability and mechanical strength but above all the efficiency in the field of photocatalysis, e.g., by increasing the activity during exposure to visible light. It has been shown that photocatalysts that are active in visible light can be modified by introducing nitrogen, sulphur, boron, carbon or a combination of these non-metals into the $\mathrm{TiO}_{2}$ structure. Therefore, the $\mathrm{TiO}_{2}$ surface is added or modified with non-metallic admixtures, ions and metal complexes, e.g., chromium $(\mathrm{Cr})$, iron $(\mathrm{Fe})$, manganese $(\mathrm{Mn})$, molybdenum $(\mathrm{Mo})$, niobium $(\mathrm{Nb})$, vanadium $(\mathrm{V})$, palladium $(\mathrm{Pd})$, ruthenium $(\mathrm{Ru})$, doping with, for example, silver $(\mathrm{Ag})$, gold $(\mathrm{Au})$ and platinum $(\mathrm{Pt})$ nanoparticles or mixing with other semiconductors such as CdS $[50,69,70]$.

During the modification, three parameters are taken into account, which determine the photocatalytic efficiency, i.e., photocatalyst activity, photocatalyst carrier, i.e., the size of the surface on which the photocatalytic reaction will take place, as well as the type and power of the radiation source. The specific surface determines the number of active centres on which the adsorption process takes place, whereas, in the case of photocatalysts, the size of the specific surface depends on the amount and size of the particles of the amorphous phase and the crystalline phase being formed. It was found that with an increase in the specific surface area, the amount of $\mathrm{OH}^{\cdot}$ radicals generated, determining the speed of the process, increases significantly [50,62,69-71].

The new elements incorporated into $\mathrm{TiO}_{2}$ act as traps for photogenerated charge carriers, reducing the rate of recombination of the electron-hole pair, which may increase the efficiency of the photocatalytic process [71,72]. Photocatalysts resulting from the modification of $\mathrm{TiO}_{2}$ can activate $\mathrm{TiO}_{2}$ with visible light. In the case of impurities, integration with $\mathrm{TiO}_{2}$ takes place and thus modifies the composition and electronic structure. The thus obtained photocatalyst is characterized by a reduced band gap energy [71,73]. On the other hand, such substances as nanoparticles of noble metals or organic dyes absorb visible light themselves and transfer the excited electron to $\mathrm{TiO}_{2}$, which allows for the initiation of the photocatalysis process $[71,74]$.

Luna et al. [71], in order to promote the photoactivity of $\mathrm{TiO}_{2}$ under the influence of solar radiation, modified $\mathrm{TiO}_{2}$ by doping with nitrogen and depositing Au nanoparticles. In addition, $\mathrm{Au} / \mathrm{N}-\mathrm{TiO}_{2}$ photocatalysts were incorporated into the silica sol to allow them 
to be sprayed onto three different building material substrates, i.e., limestone, granite and concrete. The authors indicated that the silica used in the work supports the adhesion of the photocatalyst to the substrate, increasing the durability of the photoactive coating, and, thanks to the porous structure, the diffusion of the involved substances to the active centers is possible. The results showed that Au-NP significantly improved the photoactivity of nanoparticles of $\mathrm{TiO}_{2}$, doubling the amount of $\mathrm{NO}_{x}$ removed in $\mathrm{UV}$ visible light, and the coatings increased the efficiency of removing contaminants from concrete compared to their application to limestone. However, the authors concluded that the presence of $\mathrm{Au}$ may cause clear color changes, which may in some way limit the application of the product to specific substrates [71].

Another example is modified $\mathrm{TiO}_{2}$ with carbon and nitrogen, whose sources were, respectively, methanol, ethanol and isopropanol and $\mathrm{NH}_{3}$ gas. $\mathrm{The}^{\mathrm{TiO}} \mathrm{O}_{2}-\mathrm{N}, \mathrm{C}$ modified in this way was introduced into gypsum and concrete tiles and bricks in various amounts by weight, from $1 \%$ to $20 \%$ by weight. The test results showed that for materials containing $10 \%$ by weight of $\mathrm{TiO}_{2}-\mathrm{N}, \mathrm{C}$ photocatalysts were the most effective in terms of photocatalysis. As a modifier, lauric acid was also used, which creates 80-90 nm thick domain structures on the surface of $\mathrm{TiO}_{2}$ single crystals, while irradiation with UV-Vis radiation does not change the thickness of the lauric acid layer and the surface of individual domain structures decreases. This means that the molecules located on the border of the lauric acid- $\mathrm{TiO}_{2}$-air contact are photodegraded. It has also been shown that photocatalysts with the highest activity contain $\mathrm{B}^{3+}, \mathrm{S}^{6+}$ or $\mathrm{C}-\mathrm{C}_{\text {arom }}$ in their structure and have anatase structure or are amorphous, have a developed specific surface area, and their band gap width is close to or higher than, e.g., pure $\mathrm{TiO}_{2}[75,76]$.

An example of using $\mathrm{n}-\mathrm{TiO}_{2}$ is pavement made of "anti-smog" concrete. The obtained results showed that even if the surface of the element is damaged, the concrete does not lose photocatalytic properties. Measurements carried out for two weeks showed that the $\mathrm{NO}_{x}$ concentration above a pavement made of ordinary concrete and concrete made of special TiOCem cement differed by an average of $49 \%$ in favor of the latter [77-79]. The obtained results confirm the reduction of nitrogen oxide concentrations in the air near photoactive surfaces. In a concrete product, the photocatalytically active surface under the influence of sunlight has the ability to absorb nitrogen oxides $\mathrm{NO}_{\mathrm{x}}$ and their oxidation to nitrogen ions $\mathrm{NO}_{3}{ }^{-}$, react with calcium ions and form environmentally safe salts (such as $\left.\mathrm{Ca}\left(\mathrm{NO}_{3}\right)_{2}\right)$. It should be emphasized that such installations are effective in good sunlight; on cloudy or rainy days, or when the surface is dirty, the reduction is negligible. Efficiency also depends on location and traffic [78,79].

The thickness and depth of the layer containing the photocatalyst as well as the usable form of concrete are important for the efficiency of the catalytic process [80]. Permeable, openwork surfaces have a larger contact surface with light and air, which significantly affects the efficiency of the processes of catalytic ozone and $\mathrm{NO}_{x}$ removal [80]. Permeable concrete, but without gaps, means that the lack of UV-A light penetration to a depth of $50 \mathrm{~mm}$ eliminates the possibility of photocalysis. Without excitation of electrons by UV radiation, photocatalytic oxidation of $\mathrm{NO}_{x}$ cannot occur [80]. It should be noted that surface contamination significantly limits the possibility of catalytic reduction of impurities, even up to $80-90 \%$ in the case of $\mathrm{NO}_{\mathrm{x}}$ reduction $[62,81,82]$. The $\mathrm{pH}$ value, cement composition, $\mathrm{CaCO}_{3}$ precipitation, the size and type of $\mathrm{TiO}_{2}$ particles added as well as the availability of water adsorbed on the surface, which plays an important role in the processes of photocatalytic $\mathrm{NO}_{2}$ oxidation, are also important for the efficiency of photocatalytic processes [83-85].

Photocatalysts based on $\mathrm{WO}_{3}$ are another important group of photocatalysts used in air purification processes and introduced into building materials. Among the compounds forming the volatile organic compounds (VOC) group are, among others, acetaldehyde and 2-propanol. It has been shown that it can be reduced to $\mathrm{CO}_{2}$ by approximately $90 \%$ after exposure to visible light for $60 \mathrm{~min}$ using a $110 \mathrm{~m}-\mathrm{Ag} / \mathrm{WO}_{3}$ photocatalyst [86]. However, using composite $\left(\mathrm{g}-\mathrm{C}_{3} \mathrm{~N}_{4}\right) / \mathrm{WO}_{3}$ it is possible to achieve complete decomposition and 
removal of acetaldehyde gas from the air [87]. In the case of gaseous 2-propanol (IPA), it is possible to reduce its amount in air by using a photocatalyst being a $\mathrm{NaBiO}_{3}$ composite on $\mathrm{WO}_{3}$ with a mixing ratio of 10:100, with visible light irradiation. The use of the composite allowed for a higher degree of reduction than when only $\mathrm{WO}_{3}$ was used [88].

An example of other catalysts that could be used to modify building materials, because of the demonstrated properties are $\mathrm{Fe}(\mathrm{III})-\mathrm{Fe}_{x} \mathrm{Ti}_{1-x} \mathrm{O}_{2}$ for decomposition of gaseous organic compounds, $\mathrm{CO}_{2}$ reduction, $\mathrm{NO}_{x}$ removal [89] or $\mathrm{Ag}_{3} \mathrm{PO}_{4} / \mathrm{Cr}-\mathrm{SrTiO}_{3}$ to eliminate the gaseous pollutants under visible light irradiation [90].

Analysis of the available literature indicates that the basis of the catalysts used so far in building materials is primarily $\mathrm{TiO}_{2}$. It should be added, however, that there are many factors that can determine the efficiency of photocatalysis of a modified building material. Among others, technology for building the object (e.g., highway, sidewalks, streets, walls of buildings), imposing or introducing a photocatalytic layer, its location and thickness, and methods of producing a photocatalyst are important (Table 2). 
Table 2. Examples of selected photocatalysts used in building materials to reduce pollution.

\begin{tabular}{|c|c|c|c|}
\hline Photocatalyst & Characteristic & Application & Ref \\
\hline $\mathrm{WO}_{3} / \mathrm{SrTiO}_{3} / \mathrm{TiO}_{2}$ & $\begin{array}{c}\text { at least } 5 \mathrm{wt} . \% \mathrm{TiO}_{2}-\mathrm{NPs} \text { (in anatase form) in an amount of } 0.01 \text { to } 10 \mathrm{wt} . \% \text { in relation to the } \\
\text { hydraulic binder }\end{array}$ & to reduction of NOx & [91] \\
\hline $\mathrm{TiO}_{2} / \mathrm{Al}_{2} \mathrm{O}_{3} 2 \mathrm{SiO}_{2}$ & $\begin{array}{l}\text { at least } 50 \% \text { by weight is } \mathrm{TiO}_{2} \text { in anatase form; the most optimal BET specific surface area in } \\
\text { the range from } 100 \text { to } 300 \mathrm{~m}^{2} / \mathrm{g} \text { ); metakaolin }\left(\mathrm{Al}_{2} \mathrm{O}_{3} 2 \mathrm{SiO}_{2} \text { ) as a carrier-dehydroxylated }\right. \\
\text { form of kaolinite clay mineral obtained by calcination (specific BET surface area } 12.6 \mathrm{~m}^{2} / \mathrm{g} \text { ) }\end{array}$ & $\begin{array}{l}\text { to catalyze a decomposition reaction of } \\
\text { inorganic or organic pollutants, such as: } \\
\text { polycondensates, aldehydes, } \mathrm{PM}_{10}, \mathrm{NO}_{\mathrm{x}} \text { and } \\
\qquad \mathrm{SO}_{\mathrm{x}}\end{array}$ & [92] \\
\hline $\mathrm{TiO}_{2} / \mathrm{N}, \mathrm{C}$ & $\begin{array}{l}\text { Mixtures of pure gypsum (Dolina Nidy Sp. Z O.O., Poland), porcelain mortar and } \\
\text { co-modified photocatalyst } \mathrm{TiO}_{2} / \mathrm{N}, \mathrm{C} \text { in various amounts by weight }\end{array}$ & self-cleaning properties and photocatalyst & [93] \\
\hline $\mathrm{Ru}_{\mathrm{x}} \mathrm{Ti}_{1-\mathrm{x}} \mathrm{O}_{2}$ nanobelts & $\mathrm{RuO}_{2}$ heteroatoms were introduced into the structure of $\mathrm{TiO}_{2}$ by the sol-gel method & $\begin{array}{l}\text { environmental remediation-photocatalic } \\
\text { decomposition of organic compounds }\end{array}$ & [94] \\
\hline $\mathrm{TiO}_{2}(\mathrm{P} 25)$ & $\begin{array}{l}\text { cement (Portland CEM I } 52.5 \text { R grey and white): normalized sand:water ratio of 1:3:0.5, were } \\
\text { prepared in accordance with standard EN196-1; the Aeroxide } \mathrm{TiO}_{2} \text { P25 (P25) catalyst was } \\
\text { used in 5-10\% wt. }\end{array}$ & $\begin{array}{l}\mathrm{NO}_{\mathrm{x}} \text { oxidation in different conditions of } \\
\text { humidity (RH: } 0 \text { and } 65 \% \text { ) and illumination } \\
\text { (Vis or Vis/UV) }\end{array}$ & [95] \\
\hline $\mathrm{TiO}_{2}$ & $\begin{array}{l}\text { Portland cement (OPC) CEM I 42.5R manufactured by PJSC "Ivano-Frankivskcement" and } \\
\text { composed of C3S: } 61.35, \mathrm{C} 2 \mathrm{~S}: 13.52, \mathrm{C} 3 \mathrm{~A}: 6.75, \mathrm{C} 4 \mathrm{AF}: 12.02, \text { wt.\%; natural pozzolan-zeolite } \\
\text { tuff } \mathrm{SiO}_{2} \text {, limestone powder with } 95 \text { wt. } \% \mathrm{CaCO}_{3} \text { as a micro filler; minor ultrafine } \\
\text { additives-kaolin and } \mathrm{TiO}_{2} \text {-were added to the cementing composites; TIOXIDE }{ }^{\circledR} \mathrm{R}-\mathrm{FC} 5 \\
\text { pigment (fine crystal rutile pigment), n-TiO } \mathrm{TiO}_{2} \text { powder (PC-Series) with an anatase crystalline } \\
\text { structure }\end{array}$ & $\begin{array}{l}\text { improvement of mechanical properties, } \\
\text { self-cleaning properties and photocatalyst }\end{array}$ & [96] \\
\hline
\end{tabular}


Kamegawa et al. [97] obtained a $\mathrm{TiO}_{2}$ nanocomposite coating with PTFE as a result of radio frequency magnetron sputtering (RF-S) deposition. The resulting material provides excellent hydrophobicity with a photocatalytic self-cleaning effect on a fine structure substrate. This coating technique helps to suppress changes in the wettability of the surface to a hydrophilic state and, at the same time, to have sufficient photocatalytic activity for self-cleaning [97].

Among the materials used in construction, paints containing photocatalytic substances such as $\mathrm{TiO}_{2}$ and $\mathrm{ZnO}$, which can be applied to external facades and thus improve the cleaning properties of the building, are also important. The photoactivity of $\mathrm{ZnO}$ paints was found to be much higher than with $\mathrm{TiO}_{2}$. However, during the aging process, under the influence of weather conditions, the situation changes and the paint with $\mathrm{TiO}_{2}$ increases its photoactivity. The polymer matrix degrades and the catalyst particles are better exposed. In the case of $\mathrm{ZnO}$ paints, progressive photocorrosion of $\mathrm{ZnO}$ particles has been observed [98]. Buildings made of photoactive concrete are known worldwide, such as the white Jubilee Church of Richard Meier in Rome, for which TX Millennium cement was used [99], air France building, Roissy-Charles de Gaulle Airport, in France [85], or Cite de la Musique et des Beaux Arts in Chambery [85,100,101]. According to Fujishima and Zhang [102], until 2003 self-cleaning tiles were used in more than 5000 buildings in Japan, including the Maru Building in Tokyo at the business centre [102].

An interesting issue is the use of material with the addition of a photocatalyst to cover road tunnels. Materials containing $\mathrm{TiO}_{2}$ were used in two tunnels in Europe: the Umberto I tunnel in Rome, and the Leopold II tunnel in Brussels. However, with this type of investment the problem turned out to be: lack of access to light and lack of rainfall. Photocatalytic degradation of air pollutants, especially denitrification, will only be possible if a special UV lighting system is installed. Special lighting generates additional costs and consumes energy, which reduces environmental benefits. The lack of access to water, however, causes a rapid decrease in photocatalytic activity after just a few weeks. This is because of particle deposits accumulating on the surfaces of the material that block active sites. The effectiveness of photocatalysis can be restored, partly or completely, only after washing the surface with water [103].

In the Paints and Surfaces for the Removal of Nitrogen Oxides report, the Air Quality Expert Group presented doubts about the advantages of surfaces used to remove nitrogen oxides [104]. The authors believe that it is difficult to find unambiguous and strong evidence for the effectiveness of such solutions. They claim that photocatalytic surfaces limit $\mathrm{NO}_{2}$ emissions only in their immediate vicinity and indicate the risk of nitric acid and formaldehyde formation at such installations. Moreover, a report from research at the Centre for Transportation Research, The University of Texas at Austin [81], indicates that although modelling results indicate the possibility of reducing pollution, field experiments did not show differences in concentration ozone between areas where modified $\mathrm{TiO}_{2}$ concrete was used and those where standard concrete was used [81]. It should also be taken into account that photocatalytic reactions occurring on the surface of materials and buildings may decompose and over time, and photocatalytic efficiency may change and, in the event of adverse conditions, may lead to the formation of further compounds that are dangerous to human health and the environment.

\section{Antimicrobial Properties}

From the air quality point of view, the presence of microorganisms, which not only participate in biochemical transformations but also negatively affect human health, is also important. Many microorganisms have been observed on building materials, but the most common are fungi, algae and bacteria. The presence of bacteria of the genus Arthrobacter, Aeromonas, Brevibacterium, Nitrobacter, Nocardia, Bacillus, Cyanobacteria and the classes Betaproteobacteria and Gammaproteobacteria as well as the fungi such as Alternaria, Cladosporium, Epicoccum, Udeniomyces, Aspergillus, Penicillium, Fusarium, Aspergillus has been found in building materials such as concrete, stone, glass and bricks. In contrast, 
Stachybotrys was the dominant fungus in plasterboard. The fungus Penicillium and yeasts with a number of other common types, such as Aureobasidium, Aspergillus spp., Acremonium and representatives of Sphaeropsidales, can be found in wood products, while metal structures can be colonized with sulfur bacteria (e.g., Desulfovibrio spp., Thiobacillus spp., Desulfotomaculum spp.) and ferric bacteria (Sphaerotilus spp. and Gallionella spp.). In the case of painted surfaces, bacteria of the genus Flavobacterium Pseudomonas, Micrococcus, Streptomyces as well as fungi of the genus Acremonium charticola, A. strictum, A. kiliense, Acremonium spp., Cladosporium, Mycelia sterilia, Scopulariopsis brevicaulus, Verticillium lecanii, Verticillium suchlasporium, Verticillium sp., Fusarium and Penicillium or Aspergillus versicolor and actinobacteria may be present [59,105-109].

Microorganisms on building materials, especially inside rooms, are dangerous to human health. They can produce pollutants such as allergens, spores, toxins and other metabolites that can lead to the degradation of indoor air quality and adversely affect human health, causing, among others, irritation, poisoning, superficial and systemic infections, allergies and other diseases of the respiratory system and skin [105]. A diverse population of microorganisms can also lead to the degradation of building materials, such as discoloration, cracking, corrosion, degradation of short-chain additives, material disaggregation, weakening and dissolution, and breakage of layered silicates [110].

Therefore, the addition to building materials of substances that will reduce microbial contamination plays an important role. Various inorganic substances are used to obtain concrete with antimicrobial properties, including:

- Heavy metals (Ag, Ni, W);

- Metal compounds $\left(\mathrm{Ag}_{2} \mathrm{MoO}_{4}, \mathrm{CuO}, \mathrm{ZnO}, \mathrm{Na}_{2} \mathrm{WO}_{4}, \mathrm{NaBr}\right)$;

- NORGANIX (silicate concrete sealant);

- Free $\mathrm{HNO}_{2}$;

- Nano-inorganic antimicrobial materials (such as $\mathrm{Cu}_{2} \mathrm{O}, \mathrm{CaCO}_{3}, \mathrm{TiO}_{2}, \mathrm{ZnO}, \mathrm{CuO}$, $\left.\mathrm{Al}_{2} \mathrm{O}_{3}, \mathrm{Fe}_{3} \mathrm{O}_{4}\right)$ [111].

One such substance is $\mathrm{TiO}_{2}$, which significantly reduces the growth rate of building facades with Algae Chlorella vulgaris, and sometimes even completely prevents their growth. The use of $\mathrm{TiO}_{2}$ as a modifier of building materials also allows for an increase in the purification efficiency of algae from the Chlorella mirabilis and Chroococcidiopsis fissurarum families while flushing contaminants through rainfall. Escherichia coli cells on the $\mathrm{TiO}_{2}$ coating are destroyed after an hour of intensive exposure. It has also been found that antibacterial properties are enhanced by irradiation with low UV light and modification of $\mathrm{TiO}_{2}$ with copper or silver [47].

Nanoparticles of $\mathrm{Al}_{2} \mathrm{O}_{3}, \mathrm{CuO}, \mathrm{Fe}_{3} \mathrm{O}_{4}$, and $\mathrm{ZnO}$ can also be used as cement additives, whose effects on bacteria were verified in reference to Escherichia coli, Staphylococcus aureus, Staphylococcus aureus (for biofilm formation), Pseudomonas aeruginosa and Candida albicans. The obtained research results indicate that, depending on the type of organism, metal oxide nanoparticles exhibit diverse antibacterial properties [112].

The test results of tests for antifungal activity against the fungus Cladosporium sp. on gypsum boards by Loh et al. [113] showed that $\mathrm{ZnO}$ particles were more effective than $\mathrm{TiO}_{2}$. The bactericidal properties against $E$. coli are demonstrated by the material to which $\mathrm{SiO}-\mathrm{TiO}_{2}$ composite nanoparticles have been added [114].

$\mathrm{TiO}_{2}$ modification with nitrogen and carbon allowed for the production of concrete materials with antibacterial properties. The antibacterial activity of concrete slabs in tests with Escherichia coli $\mathrm{K} 12$ was demonstrated by slabs containing in their structure 10\% by weight catalysts such as: $\mathrm{TiO}_{2} / \mathrm{N}, \mathrm{C}_{\mathrm{MeOH}^{-}} 300, \mathrm{TiO}_{2} / \mathrm{N}, \mathrm{C}_{\mathrm{EtOH}}-100, \mathrm{TiO}_{2} / \mathrm{N}, \mathrm{C}_{\mathrm{isoPrOH}}{ }^{-}$ 100 and $\mathrm{TiO}_{2} / \mathrm{N}-300$ (where the carbon was from methanol MeOH, ethanol EtOH and isopropanol isoPrOH, and nitrogen was form gaseous ammonia). It should be added, however, that the antibacterial properties differ depending on the type of photocatalyst added [115].

Verdie et al. [116] conducted work on the use of a by-product of the agri-food industry as antimicrobial coatings to protect building materials against microbial proliferation. They 
synthesized monoglycerides (MG) from oleochemical synthons such as glycerol and fatty acids. They incorporated a specific MG molecule into a translucent aqueous coating for building materials and focused on assessing the antimicrobial potential and the target. The obtained results showed that the tested MG molecule has strong antibacterial properties against Escherichia coli CIP 53126. Verdie et al. [116] found it sufficient to apply a $1 \%$ concentration of MG to the substrate to inactivate approximately $5.6 \log$ of E. coli in 24 contact hours. The use of MG as a coating limited the natural growth of microorganisms on building materials such as plasterboard.

Concrete structures used in an environment with high humidity are exposed to the influence of microorganisms through their adherence, colonization and, ultimately, destruction of the material [116].

\section{Conclusions}

Modified building materials are the answer to the worsening air quality. Thanks to photocatalysis processes, they contribute to reducing the degree of air pollution with compounds hazardous to human health, such as volatile inorganic compounds or $\mathrm{NO}_{\mathrm{x}}$ or microorganisms. Combined with the self-cleaning process, the modified materials give the opportunity to extend the lifetime of the photocatalysis process and extend the life of buildings. However, it should be taken into account that the air contains not only gaseous compounds but also dusts, whose presence significantly affects the efficiency of photocatalysis and self-cleaning processes. In the case of sorption on the surface of dusts, active sites cease to fulfill their role and the reduction of pollution drops practically to zero. Therefore, the effectiveness of a given material should be verified in real conditions. Laboratory conditions do not provide the possibility of creating an air sample that reflects the composition of real air in different places (e.g., cities, industrialized areas, villages), the impact of temperature on air quality or changes in building materials that have a significant impact on the efficiency of photocatalysis and self-cleaning processes. It is therefore necessary to carry out further work on the modification of building materials in such a way that it is possible to remove contaminants at a constant level in various environmental conditions.

Author Contributions: Conceptualization, A.R., M.Z., W.K. and A.D.; writing-original draft preparation, A.R., M.Z.; writing-review and editing, A.R., M.Z., W.K. and A.D.; project administration, A.R.; funding acquisition, W.K. and A.D. All authors have read and agreed to the published version of the manuscript.

Funding: This research was funded by the Ministry of Science and Higher Education as part of a granted subsidy for maintaining research potential in CNBOP-PIB-research work No. 025/BW/ CNBOP-PIB/MNiSW “Reaction to fire tests for construction products, interior finishing materials and cables".

Institutional Review Board Statement: Not applicable.

Informed Consent Statement: Not applicable.

Data Availability Statement: Data sharing not applicable.

Conflicts of Interest: The authors declare no conflict of interest.

\section{References}

1. Daoud, W.A. (Ed.) Self-Cleaning Materials and Surfaces. A Nanotechnology Approach; John Wiley \& Sons, Ltd.: Hoboken, NJ, USA, 2013; ISBN 9781119991779.

2. Barthlott, W. Self-Cleaning Surfaces of Objects and Process for Producing Sam. European Patent EP 0772514, 25 July 1995.

3. Nakaya, T. Development of a staining preventive coating for architecture. Prog. Org. Coat. 1996, 27, 173-180. [CrossRef]

4. Fabbri, P.; Messori, M.; Montecchi, M.; Nannarone, S.; Pasquali, L.; Pilati, F.; Tonelli, C.; Toselli, M. Perfluoropolyether-Based Organic-Inorganic Hybrid Coatings. Polymer 2006, 47, 1055-1062. [CrossRef]

5. Chermahini, S.H.; Ostad-Ali-Askari, K.; Eslamian, S.; Singh, V.P. Recent Progress in Self-Cleaning Materials with Different Suitable Applications. Am. J. Eng. Appl. Sci. 2018, 11, 560-573. [CrossRef] 
6. Kruppers, M. Cleanability of surfaces: How to describe coatings pollution characteristics and sleaning permormance. Mater. Sci. Eur. Coat. J. 2000, 10, 36-40.

7. Yang, J.; Zhang, Z.; Xu, X.; Zhu, X.; Men, X.; Zhou, X. Superhydrophilic-Superoleophobic Coatings. J. Mater. Chem. 2012, 22, 2834-2837. [CrossRef]

8. Howarter, J.A.; Youngblood, J.P. Self-Cleaning and Next Generation Anti-Fog Surfaces and Coatings. Macromol. Rapid Commun. 2008, 29, 455-466. [CrossRef]

9. Schrader, M.E. Young-Dupre Revisited. Langmuir 1995, 11, 3585-3589. [CrossRef]

10. Marmur, A. Wetting of hydrophobic rough surfaces: To be heterogeneous or not to be. Langmuir 2003, 19, 8343-8348. [CrossRef]

11. Dalawai, S.; Aly Saad Aly, M.; Latthe, S.; Xing, R.; Sutar, R.; Nagappan, S.; Ha, C. Recent Advances in durability of superhydrophobic self-cleaning technology: A critical review. Prog. Org. Coat. 2020, 138, 105381. [CrossRef]

12. Nguyen-Tria, P.; Tran, H.N.; Plamondon, C.O.; Tuduri, L.; Vo, D.-V.N.; Nanda, S.; Mishra, A.; Chao, H.-P.; Bajpai, A.K. Recent progress in the preparation, properties and applications of superhydrophobic nano-based coatings and surfaces: A review. Prog. Org. Coat. 2019, 132, 235-256. [CrossRef]

13. Sun, M.; Luo, C.; Xu, L.; Ji, H.; Ouyang, Q.; Yu, D.; Chen, Y. Artificial Lotus Leaf by Nanocasting. Langmuir 2005, $21,8978-8981$. [CrossRef]

14. Lee, H.; Lee, B.P.; Messersmith, P.B. A reversible wet/dry adhesive inspired by mussels and geckos. Nature 2007, 448, 338-341. [CrossRef] [PubMed]

15. Feng, L.; Zhang, Y.; Xi, J.; Zhu, Y.; Wang, N.; Xia, F.; Jiang, L. Petal effect: A Superhydrophobic State with High Adhesive Force. Langmuir 2008, 24, 4114-4119. [CrossRef] [PubMed]

16. Liu, M.; Wang, S.; Wei, Z.; Song, Y.; Jiang, L. Bioinspired Design of a Superoleophobic and Low Adhesive Water/Solid Interface. Adv. Mater. 2009, 21, 665-669. [CrossRef]

17. Jung, Y.C.; Bhushan, B. Wetting Behavior of Water and Oil Droplets in Three-Phase Interfaces for Hydrophobicity/philicity and Oleophobicity/philicity. Langmuir 2009, 25, 14165-14173. [CrossRef]

18. Zhao, W.; Wang, L.; Xue, Q. Fabrication of Low and High Adhesion Hydrophobic Au Surfaces with Micro/Nano-Biomimetic Structures. J. Phys. Chem. C 2010, 114, 11509-11514. [CrossRef]

19. Nishimoto, S.; Bhushan, B. Bioinspired Self-Cleaning Surfaces with Superhydrophobicity, Superoleophobicity, and Superhydrophilicity. RSC Adv. 2013, 3, 671-690. [CrossRef]

20. Söz, C.K.; Yilgör, E.; Yilgör, I. Influence of the coating method on the formation of superhydrophobic silicone-urea surfaces modified with fumed silica nanoparticles. Prog. Org. Coat. 2015, 84, 143-152. [CrossRef]

21. Koch, K.; Bhushan, B.; Barthlott, B. Diversity of structure, morphology and wetting of plant surfaces. Soft Matter 2008, 4, 1943-1963. [CrossRef]

22. Sharkskin Lotus Leaf Imitation Nano Low Resistance Antifouling Self-Cleaning Antiseize Waterproof Paint. CN101735726A, 25 November 2008.

23. Yan, L. Efficient and Low Cost Lotus Leaf Paint, and Preparation Method Thereof. CN102477244A, 26 November 2010.

24. Zielecka, M.; Bujnowska, E. Silicone-containing polymer matrices as protective coatings: Properties and applications. Prog. Org. Coat. 2006, 55, 160-167. [CrossRef]

25. Latthe, S.S.; Sutar, R.S.; Kodag, V.S.; Bhosale, A.K.; Kumar, A.M.; Kumar Sadasivuni, K.; Xing, R.; Liu, S. Self-cleaning superhydrophobic coatings: Potential industrial applications. Prog. Org. Coat. 2019, 128, 52-58. [CrossRef]

26. Mahadik, S.A.; Kavale, M.S.; Mukherjee, S.K.; Venkateswara Rao, A. Transparent superhydrophobic silica coatings on glass by sol-gel method. Appl. Surf. Sci. 2010, 257, 333-339. [CrossRef]

27. Wu, X.; Fu, Q.; Kumar, D.; Ho, J.W.C.; Kanhere, P.; Zhou, H.; Chen, Z. Mechanically robust superhydrophobic and superoleophobic coatings derived by sol-gel method. Mater. Des. 2016, 89, 1302-1309. [CrossRef]

28. Li, J.; Zhou, L.; Yang, N.; Gao, C.; Zheng, Y. Robust superhydrophobic coatings with micro and nano-composite morphology. Rsc Adv. 2017, 7, 44234-44238. [CrossRef]

29. Lee, S.G.; Ham, D.S.; Lee, D.Y.; Bong, H.; Cho, K. Transparent superhydrophobic/translucent superamphiphobic coatings based on silica-fluoropolymer hybrid nanoparticles. Langmuir 2013, 29, 15051-15057. [CrossRef]

30. Campos, R.; Guenthner, A.J.; Meuler, A.J.; Tuteja, A.; Cohen, R.E.; Mckinley, G.H.; Haddad, T.S.; Mabry, J.M. Superoleophobic surfaces through control of sprayed-on stochastic topography. Langmuir 2012, 28, 9834-9841. [CrossRef] [PubMed]

31. Mullangi, D.; Shalini, S.; Nandi, S.; Choksi, B.; Vaidhyanathan, R. Super-hydrophobic covalent organic frameworks for chemical resistant coatings and hydrophobic paper and textile composites. J. Mater. Chem. A 2017, 5, 8376-8384. [CrossRef]

32. Chen, F.; Song, J.; Lu, Y.; Huang, S.; Liu, X.; Sun, J.; Carmalt, C.J.; Parkin, I.P.; Xu, W. Creating robust superamphiphobic coatings for both hard and soft materials. J. Mater. Chem. A 2015, 3, 20999-21008. [CrossRef]

33. Han, D.; Moon, S.Y. Development of superhydrophobic surface on glass substrate by multi-step atmospheric pressure plasma treatment. Thin Solid Film. 2015, 587, 34-38. [CrossRef]

34. Qu, M.; Zhang, B.; Song, S.; Chen, L.; Zhang, J.; Cao, X. Fabrication of Superhydrophobic Surfaces on Engineering Materials by a Solution-Immersion Process. Adv. Funct. Mater. 2007, 17, 593-596. [CrossRef]

35. Li, K.; Zeng, X.; Li, H.; Li, X. A study on the fabrication of superhydrophobic iron surfaces by chemical etching and galvanic replacement methods and their anti-icing properties. Appl. Surf. Sci. 2015, 346, 458-463. [CrossRef] 
36. Baji, A.; Abtahi, M.; Ramakrishna, S. Bio-inspired electrospun micro/nanofibers with special wettability. J. Nanosci. Nanotechnol. 2014, 14, 4781-4798. [CrossRef] [PubMed]

37. Wang, H.; Zhou, H.; Niu, H.; Zhang, J.; Du, Y.; Lin, T. Nanofibrous Membranes: Dual-Layer Superamphiphobic/SuperhydrophobicOleophilic Nanofibrous Membranes with Unidirectional Oil-Transport Ability and Strengthened Oil-Water Separation Performance. Adv. Mater. Interfaces 2015, 2, 1400506. [CrossRef]

38. Li, Y.; Liu, F.; Sun, J. A facile layer-by-layer deposition process for the fabrication of highly transparent superhydrophobic coatings. Chem. Commun. 2009, 2730-2732. [CrossRef] [PubMed]

39. Quan, Y.-Y.; Zhang, L.-Z.; Qi, R.-H.; Cai, R.R. Self-cleaning of Surfaces: The Role of Surface Wettability and Dust Types. Sci. Rep. 2016, 6, 38239. [CrossRef]

40. Liu, J.; Ye, L.; Wooh, S.; Kappl, M.; Steffen, W.; Butt, H.-J. Optimizing Hydrophobicity and Photocatalytic Activity of PDMS-Coated Titanium Dioxide. ACS Appl. Mater. Interfaces 2019, 11, 27422-27425. [CrossRef]

41. Xiong, J. Durable Nanostructured Superhydrophobic Coatings on Aluminum Alloy Substrates. Master's Thesis, Université du Québec à Chicoutimi, Saguenay, QC, Canada, 2016.

42. She, Z.; Li, Q.; Wang, Z.; Li, L.; Chen, F.; Zhou, J. Researching the fabrication of anticorrosion superhydrophobic surface on magnesium alloy and its mechanical stability and durability. Chem. Eng. J. 2013, 228, 415-424. [CrossRef]

43. Xu, S.; Wang, Q.; Wang, N.; Zheng, X. Fabrication of superhydrophobic green surfaces with good self-cleaning, chemical stability and anti-corrosion properties. J. Mater. Sci. 2019. [CrossRef]

44. Stocolor Lotusan 20160114. 2019. Available online: https://www.sto-sea.com/media/documents/download_broschuere/ kategorie_fassade/StoColor_lotusan.pdf (accessed on 13 December 2020).

45. PaintPRO. 2019. Available online: http://www.paintpro.net/articles/pp705/pp705_productprofiles.cfm (accessed on 13 December 2020).

46. Carrascosa, L.A.M.; Zarzuela, R.; Badreldin, N.; Mosquera, M.J. A simple, long-lasting treatment for concrete combining hydrophobic performance with photo-induced superhydrophilic surface for easy removal of oily pollutants. ACS Appl. Mater. Interfaces 2020, 12, 19974-19987. [CrossRef] [PubMed]

47. Hashimoto, K.; Irie, H.; Fujishima, A. TiO 2 Photocatalysis: A Historical Overview and Future Prospects. Jpn. J. Appl. Phys. 2005, 44, 8269-8285. [CrossRef]

48. Wu, J.; Ren, J.; Pan, W.; Lu, P.; Qi, Y. Photo-Catalytic Control Technologies of Flue Gas Pollutants; Shanghai Jiao Tong University Press: Shanghai, China; Springer: Singapore, 2019. [CrossRef]

49. Hamidi, F.; Aslani, F. $\mathrm{TiO}_{2}$-based Photocatalytic Cementitious Composites: Materials, Properties, Influential Parameters, and Assessment Techniques. Review. Nanomaterials 2019, 9, 1444. [CrossRef]

50. Weon, S.; He, F.; Choi, W. Status and challenges in photocatalytic nanotechnology for cleaning air polluted with volatile organic compounds: Visible light utilization and catalyst deactivation. Environ. Sci. Nano 2019, 6, 3185. [CrossRef]

51. Agirseven, O.; Rivella, D.T.; Haggerty, J.E.S.; Berry, P.O.; Diffendaffer, K.; Patterson, A.; Kreb, J.; Mangum, J.S.; Gorman, B.P.; Perkins, J.D.; et al. Crystallization of $\mathrm{TiO}_{2}$ polymorphs from RF-sputtered, amorphous thin-film precursors. AIP Adv. 2020, 10, 025109. [CrossRef]

52. Luttrell, T.; Halpegamage, S.; Tao, J.; Kramer, A.; Sutter, E.; Batzill, M. Why is anatase a better photocatalyst than rutile?-Model studies on epitaxial $\mathrm{TiO}_{2}$ films. Sci. Rep. 2015, 4, 4043. [CrossRef] [PubMed]

53. Valencia, S.; Marín, J.M.; Restrepo, G. Study of the bandgap of synthesized titanium dioxide nanoparticules using the sol-gel method and a hydrothermal treatment. Open Mater. Sci. J. 2010, 4, 9-14. [CrossRef]

54. Jing, L.; Li, S.; Song, S.; Xue, L.; Fu, H. Investigation on the electron transfer between anatase and rutile in nano-sized TiO 2 by means of surface photovoltage technique and its effects on the photocatalytic activity. Sol. Energy Mater. Sol. Cells 2008, 92, 1030-1036. [CrossRef]

55. Moma, J.; Baloyi, J. Modified Titanium Dioxide for Photocatalytic Applications. In Photocatalysts-Applications and Attributes; Khan, S.B., Akhtar, K., Eds.; IntechOpen: London, UK, 2018. [CrossRef]

56. Shakeri, A.; Yip, D.; Badv, M.; Imani, S.M.; Sanjari, M.; Didar, T.F. Self-Cleaning Ceramic Tiles Produced via Stable Coating of $\mathrm{TiO}_{2}$ Nanoparticles. Materials 2018, 11, 1003. [CrossRef] [PubMed]

57. Construction \& Exterior Protection. Applications Anti-Fingerprint, Anti-Bacterial, Conductive, Ice-Repellent and Many More. Nanocoatings. Available online: https://www.mzv.cz/public/8a/2c/ba/3173333_2067163_NanoCoatings_in_Construction.pdf (accessed on 13 December 2020).

58. Banerjee, S.; Dionysiou, D.D.; Pillai, S.C. Self-cleaning applications of $\mathrm{TiO}_{2}$ by photo-induced hydrophilicity and photocatalysis. Appl. Catal. B Environ. 2015, 176, 396-428. [CrossRef]

59. Madeira, M.P.; Lobo, A.O.; Viana, B.C.; Silva Filho, E.C.; Osajima, J.A. Systems developed for application as self-cleaning surfaces and/or antimicrobial properties: A short review on materials and production methods. Cerâmica 2019, 65, 477-484. [CrossRef]

60. Ludwig, H.-M. Binding Agent Compound for Photocatalytically Active Components and Coatings. European Patent EP 2354 108 B1, 28 January 2010.

61. Guan, K. Relationship between photocatalytic activity, hydrophilicity and self-cleaning effect of $\mathrm{TiO}_{2} / \mathrm{SiO}_{2}$ films. Surf. Coat. Technol. 2005, 191, 155-160. [CrossRef] 
62. Gopalan, A.-I.; Lee, J.-C.; Saianand, G.; Lee, K.-P.; Sonar, P.; Dharmarajan, R.; Hou, I.-Y.; Ann, K.-Y.; Kannan, V.; Kim, W.-J. Recent Progress in the Abatement of Hazardous Pollutants Using Photocatalytic $\mathrm{TiO}_{2}$-BasedBuilding Materials. Nanomaterials 2020, 10, 1854. [CrossRef]

63. Miyauchi, M.; Nakajima, A.; Watanabe, T.; Hashimoto, K. Photocatalysis and Photoinduced Hydrophilicity of Various Metal Oxide Thin Films. Chem. Mater. 2002, 14, 2812-2816. [CrossRef]

64. Emeline, A.V.; Rudakova, A.V.; Sakai, M.; Murakami, T.; Fujishima, A. Factors Affecting UV-Induced Superhydrophilic Conversion of a $\mathrm{TiO}_{2}$ Surface. J. Phys. Chem. C 2013, 117, 12086-12092. [CrossRef]

65. Lüth, H. Electronic Surface States. In Surfaces and Interfaces of Solid Materials. Springer Study Edition; Springer: Berlin/Heidelberg, Germany, 1995; pp. 254-315. [CrossRef]

66. Dylla, H.; Hassan, M.M.; Mohammad, L.N.; Rupnow, T.; Wright, E. Evaluation of Environmental Effectiveness of Titanium Dioxide Photocatalyst Coating for Concrete Pavement. Transp. Res. Rec. J. Transp. Res. Board 2010, 2164, 46-51. [CrossRef]

67. Kang, X.; Liu, S.; Dai, Z.; He, Y.; Song, X.; Tan, Z. Titanium Dioxide: From Engineering to Applications. Catalysts 2019, 9, 191. [CrossRef]

68. Kumar, K.; Chowdhury, A. Use of Novel Nanostructured Photocatalysts for the Environmental Sustainability of Wastewater Treatments, Reference Module in Materials Science and Materials Engineering. Encycl. Renew. Sustain. Mater. 2020, 1, 949-964. [CrossRef]

69. Zielińska-Jurek, A.; Hupka, J. Preparation and characterization of Pt/Pd-modified titanium dioxide nanoparticles for visible light irradiation. Catal. Today 2014, 230, 181-187. [CrossRef]

70. Cinelli, M.; Coles, S.R.; Nadagouda, M.N.; Blaszczynski, J.; Slowinski, R.; Varma, R.S.; Kirwan, K. A green chemistry-based classification model for the synthesis of silver nanoparticles. Green Chem. 2015, 17, 2825-2839. [CrossRef]

71. Luna, M.; Gatica, J.M.; Vidal, H.; Mosquera, M.J. Use of Au/N-TiO $2 / \mathrm{SiO}_{2}$ photocatalysts in building materials with NO depolluting activity. J. Clean. Prod. 2020, 243, 118633. [CrossRef]

72. Katoh, R.; Furube, A.; Yamanaka, K.; Morikawa, T. Charge separation and trapping in N-Doped TiO2 photocatalysts: A time-resolved microwave conductivity study. J. Phys. Chem. Lett. 2010, 1, 3261-3265. [CrossRef]

73. Asahi, R.; Morikawa, T.; Ohwaki, T.; Aoki, K.; Taga, Y. Visible-light photocatalysis in nitrogen-doped titanium oxides. Science 2001, 293, 269-271. [CrossRef] [PubMed]

74. Nolan, N.T.; Seery, M.K.; Hinder, S.J.; Healy, L.F.; Pillai, S.C. A systematic study of the effect of silver on the chelation of formic acid to a titanium precursor and the resulting effect on the anataseto rutile transformation of $\mathrm{TiO}_{2}$. J. Phys. Chem. C 2010, 114, 13026-13034. [CrossRef]

75. Zalewska, A. Characteristics of Doped-TiO 2 photocatalysts. Physicochem. Probl. Miner. Process. 2008, 42,, 211-222. Available online: http:/ / www.minproc.pwr.wroc.pl/journal/pdf/2008/FPM\%2008\%20Zaleska.pdf (accessed on 13 December 2020).

76. Zalewska, A.; Grabowska, E.; Sobczak, J.W.; Gazda, M.; Hupka, J. Photocatalytic activity of boron-modified TiO ${ }_{2}$ under visible light: The effect of boron content, calcination temperature and $\mathrm{TiO}_{2}$ matrix. Appl. Catal. B Environ. 2009, 89, 469-475. [CrossRef]

77. Hanson Cement, TioCem ${ }^{\circledR R}$ Reducing Pollution in the Urban Environment. Hanson Cement, Ketton Stamford Rutland PE9 3SX. Available online: www.hanson.co.uk (accessed on 15 February 2021).

78. Bolte, G. Innovative Building Material-Reduction of Air Pollution through TioCem ${ }^{\circledR}$. In Nanotechnology in Construction 3; Bittnar, Z., Bartos, P.J.M., Němeček, J., Šmilauer, V., Zeman, J., Eds.; Springer: Berlin/Heidelberg, Germany, 2009.

79. De Dios, J.; del Campo, J.M.; Colorado, D. Decontamination through Photocatalytic $\mathrm{TiO}_{2}$ Additions-Past, Present and Future. In Proceedings of the 2nd International Conference on Emerging Trends in Engineering and Technology (ICETET'2014), London, UK, 30-31 May 2014. [CrossRef]

80. Asadi, S.; Hassan, M.M.; Kevern, J.T.; Rupnow, T.D. Development of Photocatalytic Pervious Concrete Pavement for Air and Storm Water Improvements. Transp. Res. Rec. J. Transp. Res. Board 2012, 2290. [CrossRef]

81. Crain, N.; Juenger, M.; Cros, C.; Terpeluk, A.; Burris, L.; McDonald-Buller, E.; Sullivan, D.; Kimura, Y.; Spinhirne, J. Laboratory and Field Studies of Photocatalytic $\mathrm{NO}_{x}$ and $\mathrm{O}_{3}$ Removal by Coatings on Concrete. Technical Report, 2017. 9/01/2010-12/31/2016. Available online: http:/ /library.ctr.utexas.edu/ctr-publications/0-6636-1.pdf (accessed on 13 December 2020).

82. Etxeberria, M.; Guo, M.-Z.; Maury-Ramirez, A.; Poon, C.S. Influence of dust and oil accumulation on effectiveness of photocatalytic concrete surfaces. J. Environ. Eng. 2017, 143. [CrossRef]

83. Vagenas, N.V.; Gatsouli, A.; Kontoyannis, C.G. Quantitative analysis of synthetic calcium carbonate polymorphs using FT-IR spectroscopy. Talanta 2003, 59, 831-836. [CrossRef]

84. Yang, L.; Hakki, A.; Wang, F.; Macphee, D.E. Photocatalyst efficiencies in concrete technology: The effect of photocatalyst placement. Appl. Catal. B Environ. 2018, 222, 200-208. [CrossRef]

85. Topçu, I.B.; Akkan, E.; Uygunoğlu, T.; Çalişkan, K. Self-Cleaning Concretes: An Overview. J. Cem. Based Compos. 2020, 2, 6-12. [CrossRef]

86. Sun, S.; Wang, W.; Zeng, S.; Shang, M.; Zhang, L. Preparation of ordered mesoporous Ag/WO 3 and its highly efficient degradation of acetaldehyde under visible-light irradiation. J. Hazard Mater. 2010, 178, 427-433. [CrossRef] [PubMed]

87. Katsumata, K.-I.; Motoyoshi, R.; Matsushita, N.; Okada, K. Preparation of graphitic carbon nitride $\left(\mathrm{g}-\mathrm{C}_{3} \mathrm{~N}_{4}\right) / \mathrm{WO}_{3}$ composites and enhanced visible-light-driven photodegradation of acetaldehyde gas. J. Hazard Mater. 2013, 260, 475-482. [CrossRef]

88. Kako, T.; Meng, X.; Ye, J. Solid-base loaded $\mathrm{WO}_{3}$ photocatalyst for decomposition of harmful organics under visible light irradiation. Appl. Mater. 2015, 3, 104411. [CrossRef] 
89. Liu, M.; Qiu, X.; Miyauchi, M.; Hashimoto, K. Energy-Level Matching of Fe(III) Ions Grafted at Surface and Doped in Bulk for Efficient Visible-Light Photocatalysts. J. Am. Chem. Soc. 2013, 135, 10064-10072. [CrossRef]

90. Guo, J.; Ouyang, S.; Li, P.; Zhang, Y.; Kako, T.; Ye, J. A new heterojunction $\mathrm{Ag}_{3} \mathrm{PO}_{4} / \mathrm{Cr}-\mathrm{SrTiO}$ photocatalyst towards efficient elimination of gaseous organic pollutants under visible light irradiation. Appl. Catal B 2013, 134, 286-292. [CrossRef]

91. Milan, L.C.; Bergamo, C.P. Hydraulic Binder and Cement Compositions Containing Photocatalyst Particles. U.S. Patent No. US 6,409,821 B1, 25 June 2002.

92. Brindisi, R.A.; Bergamo, M.B.; San Donato Milanese, L.C. Titanium Dioxide Based Photocatalytic Composites and Derived Products on a Metakaolin Support. U.S. Patent US 2010/0266472 A1, 21 October 2010.

93. Janus, M.; Bubacz, K.; Zatorska, J.; Kusiak-Nejman, E.; Czyżewski, A.; Morawski, A.W. Preliminary studies of photocatalytic activity of gypsum plasters containing $\mathrm{TiO}_{2}$ co-modified with nitrogen and carbon. Pol. J. Chem. Technol. 2015, 17, 96-102. [CrossRef]

94. Mihai, S.; Cursaru, D.L.; Matei, D.; Manta, A.M.; Somoghi, R.; Branoiu, G. Rutile $\mathrm{Ru}_{\mathrm{x}} \mathrm{Ti}_{1-\mathrm{x}} \mathrm{O}_{2}$ nanobelts to enhance visible light photocatalytic activity. Sci. Rep. 2019, 9, 18798. [CrossRef] [PubMed]

95. Hernández-Rodríguez, M.J.; Santana Rodríguez, R.; Darias, R.; González Díaz, O.; Pérez Luzardo, J.M.; Doña Rodríguez, J.M.; Pulido Melián, E. Effect of $\mathrm{TiO}_{2}$ Addition on Mortars: Characterization and Photoactivity. Appl. Sci. 2019, 9, 2598. [CrossRef]

96. Sanytsky, M.; Kropyvnytska, T.; Hohol, M.; Kotiv, R. Nano-modified cementing composites for self-cleaning building materials. Constr. Optim. Energy Potential 2020, 9, 7-14. [CrossRef]

97. Kamegawa, T.; Shimizu, Y.; Yamashita, H. Superhydrophobic Surfaces with Photocatalytic Self-Cleaning Properties by Nanocomposite Coating of $\mathrm{TiO}_{2}$ and Polytetrafluoroethylene. Adv. Mater. 2012, 24, 3697-3700. [CrossRef]

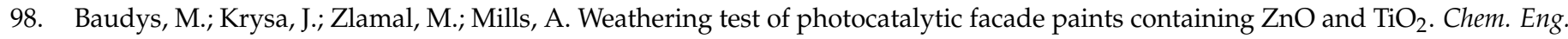
J. 2015, 261, 83-87. [CrossRef]

99. Cardellicchio, L. Our Future Heritage. Ageing Patterns of Contemporary Concrete: The Case Study of the Jubilee Church by Richard Meier in Rome. In Proceedings of the International Conference on Construction Research-EDUARDO TORROJA. Architecture, Engineering, Concrete/AEC, Madrid, Spain, 23 November 2018.

100. Cassar, L.; Pepe, C.; Tognon, G.; Guerrini, G.L.; Amadelli, R. White cement for architectural concrete, possessing photocatalytic properties. In Proceedings of the 11th International Congress on the Chemistry of Cement, The Cement and Concrete Institute of South Africa, Durban, South Africa, 16 May 2003; Volume 4, pp. 2012-2021.

101. Guerrini, G.L.; Plassais, A.; Pepe, C.; Cassar, L. Use of photocatalytic cementitious materials for self-cleaning applications. In Proceedings of the International RILEM Symposium on Photocatalysis, Environment and Construction Materials-TDP 2007, Florence, Italy, 8-9 October 2007; Volume 55, pp. 219-226.

102. Fujishima, A.; Zhang, X. Titanium dioxide photocatalysis: Present situation and future approaches. Comptes Rendus Chim. 2006, 9 , 750-760. [CrossRef]

103. Bernagaud, C.; Burkhart, J.F.; Vidal, B.; Yaghzar, M. The Treatment of Airin Road Tunnels. State-of-the-Art of Studies and Works Tunnels Study Centre. BRON_FRANCE. 2016. Available online: http:/ /www.cetu.developpement-durable.gouv.fr/IMG/pdf/ cetu_di_traitement_de_1_air-en-19_07_2017.pdf (accessed on 28 January 2020).

104. Air Quality Expert Group. Paints and Surfaces for the Removal of Nitrogen Oxides; Department for Environment, Food and Rural Affairs: London, UK, 2016.

105. Verdier, T.; Coutand, M.; Bertron, A.; Roques, C. A review of indoor microbial growth across building materials and sampling and analysis methods. Build. Environ. 2014, 80, 136-149. [CrossRef]

106. Kurowski, G.; Vogt, O.; Ogonowski, J. Paint-degrading microorganisms. Tech. Trans. 2017, 12, 81-92. [CrossRef]

107. Giannantonio, D.J.; Kurth, J.C.; Kurtis, K.E.; Sobecky, P.A. Molecular characterizations of microbial communities fouling paintedand unpainted concrete structures. Int. Biodeterior. Biodegrad. 2009, 63, 30-40. [CrossRef]

108. Liengen, T.; Feron, D.; Basseguy, R.; Beech, I.B. (Eds.) Understanding Biocorrosion Fundamentals and Applications European Federation of Corrosion Publications NUMBER 66; Woodhead Publishing Limited, Elsevier: Amsterdam, The Netherlands, 2014 ; p. 447.

109. Hyvärinen, A.; Meklin, T.; Vepsäläinen, A.; Nevalainen, A. Fungi and actinobacteria in moisture-damaged building materialsConcentrations and diversity. Int. Biodeterior. Biodegrad. 2002, 49, 27-37. [CrossRef]

110. Gaylarde, C.; Ribas Silva, M.; Warscheid, T. Microbial impact on building materials: An overview. Mat. Struct. 2003, 36, 342-352. [CrossRef]

111. Qiu, L.; Dong, S.; Ashour, A.; Han, B. Antimicrobial concrete for smart and durable infrastructures: A review. Constr. Build Mater. 2020, 260, 120456. [CrossRef] [PubMed]

112. Sikora, P.; Augustyniak, A.; Cendrowski, K.; Nawrotek, P.; Mijowska, E. Antimicrobial Activity of $\mathrm{Al}_{2} \mathrm{O}_{3}, \mathrm{CuO}, \mathrm{Fe}_{3} \mathrm{O}_{4}$, and $\mathrm{ZnO}$ Nanoparticles in Scope of Their Further Application in Cement-Based Building Materials. Nanomaterials 2018, 8, 212. [CrossRef] [PubMed]

113. Loh, K.; Gaylarde, C.C.; Shirakawa, M.A. Photocatalytic activity of $\mathrm{ZnO}$ and $\mathrm{TiO}_{2}$ 'nanoparticles' for use in cement mixes. Constr. Build. Mater. 2018, 167, 853-859. [CrossRef]

114. Sikora, P.; Cendrowski, K.; Markowska-Szczupak, A.; Horszczaruk, E.; Mijowska, E. The effects of silica/titania nanocomposite on the mechanical and bactericidal properties of cement mortars. Constr. Build. Mater. 2017, 150, 738-746. [CrossRef] 
115. Janus, M.; Kusiak-Nejman, E.; Rokicka-Konieczna, P.; Markowska-Szczupak, A.; Zając, K.; Morawski, A.W. Bacterial Inactivation on Concrete Plates Loaded with Modified $\mathrm{TiO}_{2}$ Photocatalysts under Visible Light Irradiation. Molecules 2019, 24, 3026. [CrossRef] [PubMed]

116. Verdier, T.; Bertron, A.; Valentin, R.; Nyame Mendendy Boussambe, G.; Mouloungui, Z.; Roques, C. Monoglyceride to protect building materials against microbial proliferation. Matériaux Tech. 2017, 104, 508. [CrossRef] 